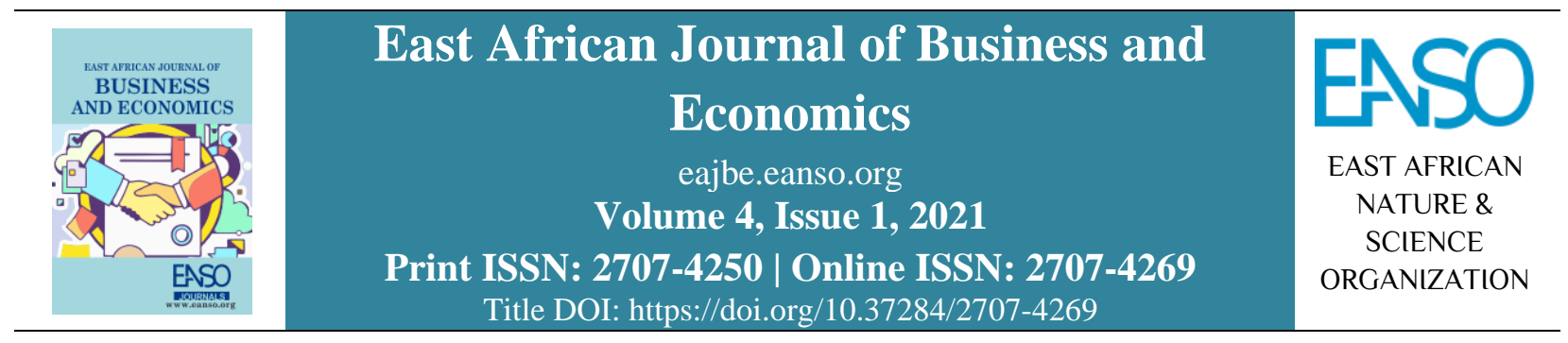

Original Article

\title{
Factors Affecting the Adoption of Financial Reporting Standards by Micro, Small and Medium Enterprises in Tanzania: The Case of Mbeya City Council.
}

\author{
Benance Lackson ${ }^{1 *} \&$ Dr. Seif Muba \\ ${ }^{1}$ Mzumbe University Tanzania, P. O. Box 1 , Morogoro, Tanzania. \\ *Correspondence ORCID ID: https://orcid.org/0000-0002-7430-8062; email: benance.lackson19@ mustudent.ac.tz
}

Article DOI: https://doi.org/10.37284/eajbe.4.1.480

\section{Date Published: ABSTRACT}

25 November 2021 Different studies have revealed that the majority of the micro, small and medium enterprises (MSMEs) in Tanzania do not use basic

Keywords: accounting principles and practices which are consistent with financial reporting standards in managing business though Tanzania adopted

Adoption, International Financial Reporting Standards for small and medium MSMEs, enterprises (IFRS for SMEs) in 2009 and issued financial reporting

Financial Reporting

Standards,

Factors Affecting,

Tanzania. standard for Micro entities in 2018. This shows that the level of adoption and applicability of the standards is very low. Therefore, this study was carried out to assess factors that affect the adoption of financial reporting standards by MSMEs in Tanzania. The study was conducted in Mbeya City Council where primary data was collected from a sample size of 245 respondents via a Likert scale questionnaire. The descripto-explanatory research design was employed where the results were quantitatively analysed through descriptive statistics and chi-square $\left(\mathrm{x}^{2}\right)$ model hypothesis testing. The results show that nonadoption of the standards was the result of inadequate knowledge by MSMEs, lack of awareness by most MSMEs on the existence of the standards, high perceived cost of conversion and implementation, weak legal and regulatory enforcement strategy, low level of technology applicability by SMEs and complexity of the standards as it needs a well-trained accountant to implement. The study recommends the government to come up with the implementation strategy that will first ensure that a large number of MSMEs is well trained on financial reporting standards because the decision to adopt or not to adopt largely depend on the adequacy of knowledge.

46 This work is licensed under a Creative Commons Attribution 4.0 International License. 


\section{APA CITATION}

Lackson, B., \& Muba, S. (2021). Factors Affecting the Adoption of Financial Reporting Standards by Micro, Small and Medium Enterprises in Tanzania: The Case of Mbeya City Council. East African Journal of Business and Economics, 4(1), 46-61. https://doi.org/10.37284/eajbe.4.1.480

\section{CHICAGO CITATION}

Lackson, Benance \& Seif Muba. 2021. "Factors Affecting the Adoption of Financial Reporting Standards by Micro, Small and Medium Enterprises in Tanzania: The Case of Mbeya City Council". East African Journal of Business and Economics 4 (1), 46-61. https://doi.org/10.37284/eajbe.4.1.480.

\section{HARVARD CITATION}

Lackson, B., \& Muba, S. (2021) "Factors Affecting the Adoption of Financial Reporting Standards by Micro, Small and Medium Enterprises in Tanzania: The Case of Mbeya City Council”, East African Journal of Business and Economics, 4(1), pp. 46-61. doi: 10.37284/eajbe.4.1.480.

\section{IEEE CITATION}

B. Lackson, \& S. Muba, "Factors Affecting the Adoption of Financial Reporting Standards by Micro, Small and Medium Enterprises in Tanzania: The Case of Mbeya City Council”, EAJBE, vol. 4, no. 1, pp. 46-61, Nov. 2021.

\section{MLA CITATION}

Lackson, Benance \& Seif Muba. "Factors Affecting the Adoption of Financial Reporting Standards by Micro, Small and Medium Enterprises in Tanzania: The Case of Mbeya City Council". East African Journal of Business and Economics, Vol. 4, no. 1, Nov. 2021, pp. 46-61, doi:10.37284/eajbe.4.1.480.

\section{INTRODUCTION}

Financial reporting standards are accounting rules and principles developed by the international accounting standards board (IASB) to ensure common financial reporting framework between businesses globally. The standards were established to increase transparency, accountability, uniformity, and comparability of financial information between or within entities (International Accounting Standards Board, 2015). The IASB in 2009 issued international financial reporting standards for small and medium enterprises (IFRS for SMEs) to provide an alternative reporting framework for SMEs in place of Full IFRSs. The establishment of IFRS for SMEs emerged because many countries successfully adopted full IFRS for publicly accountable entities but faced challenges in the adoption of the standards by SMEs (Mkasiwa, 2014). Therefore, this necessitated the issue of IFRS for SMEs which are considered as simple to apply as compared to full IFRS (IASB, 2020).

Tanzania being a member of IASB adopted IFRS for SMEs in 2009 and issued Financial Reporting Standards for Micro entities (FRSMEs) in 2018. Different scholars have indicated that even after the adoption and issue of the standards, still the majority of the SMEs do not use best accounting practices and principles that are consistent with financial reporting standards in managing the business (Mwakujonga \& Bwana, 2013; Guyashi \& Miku, 2015: Lukumay, 2018). Further, the study conducted by Msuya and Maleko (2015) on the adoption of IFRS by SACOSS in Shinyanga revealed that the level of compliance is very low. Nzunda (2013) in his study conducted in Morogoro observed that the level of compliance to IFRS by SMEs was 0\%. Moreover, Kibona (2020) in his study conducted in Kibaha revealed that financial reporting and analysis are inadequately practised by MSMEs. All this indicates that the level of compliance to the adopted and issued standards is still very low.

With regard to the above, this study was motivated and carried out to assess factors that affect the adoption of financial reporting standards by Micro, Small, and medium enterprises in Tanzania. This is because no similar studies have been conducted and the few studies conducted were assessing the adoption of full IFRS. Based on the general study objective, the following five research questions were formulated: How does the existing level of 
education and training affect the adoption of financial reporting standards? What are the effects of conversion cost on the adoption of financial reporting standards? How does the existing legal and regulatory enforcement strategy affect the adoption of financial reporting standards? What is the effect of technology on the adoption of financial reporting standards? And, how does the complexity of the standards affect the adoption of financial reporting standards?

The study results and conclusion narrow the existing empirical gap and provided crucial information to policy and other decision-makers for the improvement and sustainability of MSMEs.
There is no common definition of SMEs that can be used globally; different countries depending on the level of development use different measures to define what SMEs are. The most used measures include the number of employees, capital invested, and sale turnover (Berisha \& Pula, 2015). IFRS Foundation (2015) defines SMEs as those entities which do not have public accountability but are required to prepare and issue general purpose financial statements to external users. In the context of Tanzania, SMEs sometimes represent micro, small, and medium enterprises (MSMEs) and has been defined based on the number of employees and the amount of capital invested as indicated in table 1 below.

\section{LITERATURE REVIEW}

\section{Theoretical Review}

Table 1: Classification of SMEs

\begin{tabular}{lll}
\hline Category & Number of employees & Capital investment in machineries (in TZS) \\
\hline Micro enterprises & $1-4$ & Up to 5 million \\
Small enterprises & $5-49$ & Above 5 million to 200 million \\
Medium enterprises & $50-99$ & Above 200 million to 800 million \\
Large enterprises & $100+$ & Above 800 million \\
\hline
\end{tabular}

Source: Small and Medium Enterprise Development Policy, 2003

The policy further requires the level of investment to be used as a deciding factor in case of enterprises fall under more than one category. In Tanzania, the scope of applicability of the concerned standards are as follows; For entities that do not have public interest, have a turnover of Tshs 800 million or above, and total assets value of TZS. TZS 400 million or above are permitted to use IFRS for SEMs and entities which do not have public interest and meet at least two of the following condition a permitted to use financial reporting standard for Micro entities has a turnover of less than TZS. TZS 800 million has total assets with a value of less than TZS. TZS 400 million or has an average number of employees of not more than 10 (National Board of Accountant and Auditors (NBAA, 2018).
For the purpose of this study, the institutional theory was used. Institution theory assumes that organisational structure and procedure depend on external factors for social fitness (Moll et al., 2006). The main idea behind the institutional theory is an institutional isomorphism or pressure which advocates those changes in structures and practices of an organisation that can be influenced by either one or more of the three sources of pressures, namely coercive, mimetic and normative (DiMaggio and Powell, 1983). Coercive isomorphism describes the effect of laws or regulations towards the adoption and adherence to the particular practice or structure. Mimetic describe the situation where the entity copy or imitate the behaviour or norm of other successful organisation provided that it deals with a similar issue and normative advocate that an institution 
adopts what they think are the best practices as it has been certified by the professional body or any other authoritative source in order to become more successful (DiMaggio \& Powell, 1983). Therefore, a detailed examination of the aforementioned three forms of institutional isomorphism or pressure offers a great opportunity to assess factors that affect the adoption of financial reporting standards through assessment of different internal and external factors

\section{Empirical Review and Hypotheses Development}

\section{Education Level and Training}

The nature of the modern accounting environment requires regular updating of the knowledge possessed by accountants in order to match the changes occurring in the accounting profession and their professional competence in accounting for different financial transactions and preparation of financial statements (Zeghal \& Mhedhbi, 2006). The study conducted by Adekoya (2011) revealed that among the challenges faced during the implementation of IFRS in Nigeria was the shortage of professional accountants and auditors. However, the study conducted by Kaya and Koch (2015) revealed that there is no relationship between education level and decision on adoption of IFRS for SMEs. This brings inconsistency in results about education and adoption of accounting standards. Therefore, the following relationship was hypothesised.

$\mathbf{H}_{1}$ : Education level and training has a significant effect on the adoption of financial reporting standards by MSMEs

\section{Cost of Conversion}

For SMEs to adopt IFRS for SMEs and apply it effectively to business, they need to engage an expert; this can involve either employing an accountant with knowledge on IFRS for SMEs or engaging an external consultancy. The study conducted by Jayabalan and Dorasamy (2009) in
Malaysia revealed that the high cost of hiring professional accountants causes SME managers or owners to relegate accounting information management. A similar result was reported on the studies conducted by Hussain et al. (2012) and Litjens et al. (2012) with regard to the cost of the adoption of IFRS for SMEs. However, Albu (2013) in his studies reported that stakeholders do not consider adoption and implementation of IFRS for SMEs as a cost burden but as an opportunity for improving the quality of accounting information which will result in the provision of quality information to different users for decision making. This brings inconsistency on results; therefore, the following relationship was hypothesised

$\mathbf{H}_{2}$ : Cost of conversion has a significant effect on the decision to adopt financial reporting standards by MSMEs

\section{Legal and Regulatory Enforcement Strategy}

legal issues mostly work to gather with regulatory function. According to Alia and Branson (2011) legal environment directly determines how the accounting system is regulated in a particular country. In Africa incapacity of the regulatory body to enforce is among the major factors that were reported to hinder the adoption and implementation of IFRS for SMEs (Kenneth \& Grazyina, 2013). Based on this fact researcher intend to know whether the decision for SMEs to adopt or not to adopt IFRS for SMEs or FRSMEs is significantly affected by the country's level of appropriateness in term of the legal and regulatory body. Therefore, the following relationship was hypothesised

$\mathbf{H}_{3}$ : Legal and regulatory enforcement strategy has a significant effect on the decision to adopt financial reporting standards by MSMEs

\section{Technology Factors}

Successful implementation of the IFRS depends on the existence of formidable information technology supporting structure and the absence of such 
structure has been one of the key progress limiting factors on adoption of IFRS (Emekaponuzo et al., 2017). However, Information technology represents the most Significant costs of IFRS adaptation which cause small organisations and those embarking on cost-saving measures to fail to adapt to new information systems and remain with the existing information systems (Khoury, 2009). Therefore, based on the above view relating to the cost and benefit associated with technology the researcher what to assess if technology affects the adoption of the IFRS for SMEs in Tanzania.

$\mathbf{H}_{4}$ : Technology has a significant effect on the decision to adopt financial reporting standards by MSMEs

\section{Standards Complexity}

It was reported by IFAC (2007) that Africa countries face challenges of inadequate professional accountants who are technically trained on IFRS (technical capacity). There is a perception from the SMEs that IFRS for SME still is complex for small and medium enterprises to apply, this is evidenced by the study conducted by Perera and Chand (2015), the study reported that a number of countries have not well adopted IFRS for SMEs due to perception of being a burden to small and micro entities, technical difficulties in some section of the IFRS for SMEs and the prospective complexity in preparation of the financial statement by the SMEs. Therefore, the researcher intends to assess if factors relating to the technical and complexity of the standards held in Tanzania. With this regard, the following hypothesis was tested:

H$_{5}$ : standards complexity has a significant effect on the decision to adopt financial reporting standards by MSMEs

\section{Conceptual Framework}

A conceptual framework was formulated for this study to indicate the dimension of factors that affect the adoption of financial reporting standards. The factors were determined with reference to literature reviewed (Adekoya, 2011; Kaya \& Koch, 2015; Jayabalan \& Dorasamy, 2009; Hussain et al., 2012; Albu, 2013; Alia \& Branson, 2011; Kenneth \& Grazyina, 2013; Emekaponuzo et al., 2017; Khoury, 2009; Perera \& Chand, 2015). Independent variables were measured on a Likert scale, while the dependent variable was measured by the level of compliance. The diagrammatic representation of the conceptual framework is as in Figure 1 below:

\section{Figure 1: Conceptual Framework}

\section{Independent variables}

- Education and training factors

- Cost of conversion

- Legal and regulatory enforcement strategy

- Technological factors

- Standards complexity factors

\section{Dependent variables}

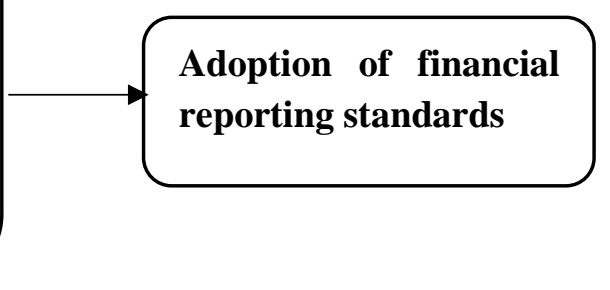

\section{METHODOLOGY}

The study was conducted in the Mbeya City Council from which a sample size of 245 respondents was established through Cochran's formula. Cochran's formula is appropriate for a large population and where the total population is not well defined 
(Cochran, 1977). The area was selected because no similar studies have been conducted. The study used both primary and secondary data. Primary data was used as a main source of data and was collected via questionnaires. Secondary data was used to clarify the study findings.

Likert scale questionnaires were used to collect data. The assessed variables on each factor were rated on a five-point Likert scale with $1=$ strongly disagree, $2=$ disagree, $3=$ neutral, $4=$ =agree, and $5=$ strongly agree; respondents were asked to express their level of agreement. Non- probability sampling technique was used to select respondents. The selection was based on researcher judgment. The technique helped the researcher to obtain accurate and reliable information because the researcher selected respondents who best suited the study and who were willing and able to respond to the research questions

The study was descripto-explanatory in nature; therefore, descriptive and explanatory research design at a different stage. According to Saunders et al. (2009), a descripto-explanatory study is a study that uses both descriptive and explanatory design where the description is the precursor to an explanation. Descriptive statistics like frequency tables and mean values were used to describe phenomena or events from which little is known and an explanatory research design was used to identify how the independent variable influence the dependent variable. The cause-and-effect relationship was analysed through the Chi-square $\left(x^{2}\right)$ model which was used to measure the hypothesis. This is one of the important significant tests and it bases on frequencies (Kaur, 2013).

\section{PRESENTATION OF STUDY RESULTS}

\section{Response Rate}

From the sample of 245 respondents, only 216 questionnaires equivalent to $88.16 \%$ were responded and returned of which 203 had a usable response equivalent to $82.86 \%$ of the total questionnaires distributed, 6 questionnaires equivalent to $2.45 \%$ were found to be out of the scope of MSMEs and 7 questionnaires equivalent $2.86 \%$ were containing the unusable response.

\section{Data Reliability Test}

A reliability test or internal consistency of the Likert scale variables was performed using Cronbach's alpha via SPSS. The results are presented in Table 2 below:

\section{Table 2: Reliability test result}

\begin{tabular}{lll}
\hline Variable & Cronbach's Alpha & Number of items \\
\hline Education and awareness related factors & 0.735 & 8 \\
Cost of conversion-related factors & 0.814 & 6 \\
Legal and regulatory enforcement related factors & 0.737 & 4 \\
Technological related factors & 0.757 & 5 \\
Technical and complexity related factors & 0.783 & 5 \\
\hline
\end{tabular}

Table 2 above includes the value of Cronbach's alphas which are within the acceptable range for data analysis. The acceptable value of the Cronbach's Alpha for data analysis ranges from 0.7 to 0.95 as too high Cronbach's alpha coefficient tells that some items are redundant because they test the same question in a different guise (Tavakol \& Dennick, 2011). 
East African Journal of Business and Economics, Volume 4, Issue 1, 2021

Article DOI: https://doi.org/10.37284/eajbe.4.1.480

\section{Factors that Affect the Adoption of Financial Level of Education and Training on Financial Reporting Standards \\ Reporting Standards}

Based on the conceptual framework and study objectives, the following factors were assessed:

The distribution of the response is as presented in

Table 3 below:

Table 3: Level of education and training

\begin{tabular}{|c|c|c|c|c|c|c|c|c|}
\hline Assertions & SD & D & $\mathbf{N}$ & A & SA & Mean & Remarks & Ranking \\
\hline $\begin{array}{l}\text { Enterprise owners and cashier or } \\
\text { accounting staff have limited or no } \\
\text { knowledge of financial reporting } \\
\text { standards }\end{array}$ & 3 & 6 & 32 & 111 & 51 & 3.99 & Agree & 2 \\
\hline $\begin{array}{l}\text { little is known by SMEs about the } \\
\text { benefits associated with the adoption of } \\
\text { financial reporting standards }\end{array}$ & 4 & 23 & 7 & 94 & 75 & 4.05 & Agree & 1 \\
\hline $\begin{array}{l}\text { There is a shortage of educational } \\
\text { institutions which train accountancy; } \\
\text { this causes a low supply of accountant }\end{array}$ & 35 & 91 & 28 & 48 & 1 & 2.45 & Disagree & 8 \\
\hline $\begin{array}{l}\text { There is a shortage of well-trained } \\
\text { professional accountants for the } \\
\text { adoption of financial reporting } \\
\text { standards at the business place }\end{array}$ & 7 & 40 & 29 & 79 & 48 & 3.60 & Agree & 6 \\
\hline $\begin{array}{l}\text { Little is known on the key difference } \\
\text { between reporting framework, i.e., } \\
\text { FRSME, Full IFRS, IFRS for SME, and } \\
\text { IPSASs which bring controversial on } \\
\text { which to apply }\end{array}$ & 4 & 12 & 105 & 57 & 25 & 3.43 & Agree & 7 \\
\hline $\begin{array}{l}\text { There is a low level of consistency } \\
\text { between educational programs and } \\
\text { practice at the workplace }\end{array}$ & 4 & 7 & 51 & 114 & 27 & 3.75 & Agree & 4 \\
\hline $\begin{array}{l}\text { There is inadequate training through } \\
\text { workshops and seminars to owners, } \\
\text { accountants and other users of the } \\
\text { financial information }\end{array}$ & 3 & 5 & 62 & 109 & 24 & 3.72 & Agree & 5 \\
\hline $\begin{array}{l}\text { There is inadequate practical training on } \\
\text { the financial reporting standards } \\
\text { conversion process }\end{array}$ & 3 & 7 & 46 & 89 & 58 & 3.95 & Agree & 3 \\
\hline
\end{tabular}

As per Table 3 above majority of the respondents either agreed or strongly agreed with most of the assertion which indicates that there is inadequate education and training which hinder the adoption of financial reporting standards by MSMEs. However, respondents disagreed and strongly disagreed that there is a shortage of educational institutions that train accountancy which result in the low supply of accountant. Ranked highest is an assertion which states that little is known by SMEs about the benefits associated with the adoption of financial reporting standards where 94 respondents agreed (46.3\%), and 75 strongly agreed (36.9\%) with the mean value of 4.05 , altogether covering $83.2 \%$ of the total respondent. $79.8 \%$ of the respondents either agreed (111) or strongly agreed (51) that enterprises owners and cashier or accounting staff have limited or no knowledge of financial reporting standards. Generally, in all assertions, respondents agreed or strongly agreed except for the assertion 
which state that there is a shortage of educational institutions that train accountancy. However, due to inadequate knowledge on the available reporting standards majority (105) of the respondents decided to respond neutrally to the assertion which stated that little is known on the key difference between reporting framework which brings controversy on which one to apply, but for those who decided majority (82) either agreed $(28.1 \%)$ or strongly agreed (12.3\%).
Hypothesis testing was performed through the use of the Chi-square $\left(\mathrm{x}^{2}\right)$ model and the obtained Pvalue of 0.034 was less than the critical value of 0.05 . These results provide statistical evidence to accept the hypothesis and conclude that education level and training have a significant effect on the adoption of financial reporting standards. The hypothesis test results are indicated in Table 4 below:

Table 4: Chi-square (x2) table for testing Hypothesis 1

\begin{tabular}{llll}
\hline & Value & df & Asymptotic Significance. (2-sided) \\
\hline Pearson Chi-Square & $45.562^{\mathrm{a}}$ & 30 & .034 \\
Likelihood Ratio & 44.008 & 30 & .048 \\
Linear-by-Linear Association & 11.974 & 1 & .001 \\
N of Valid Cases & 62 & & \\
\hline
\end{tabular}

Cost of Conversion and Adoption of Financial Reporting Standards
With regards to the cost of conversion-related factors, descriptive statistics results are summarised in Table 5 below:

Table 5: Cost of conversion and adoption of financial reporting standards

\begin{tabular}{lllllllll}
\hline Assertions & SD & D & N & A & SA & Mean & Remarks & Rankings \\
\hline $\begin{array}{l}\text { Cost of changing or upgrading } \\
\text { accounting information system during } \\
\text { the first adoption is high }\end{array}$ & 7 & 29 & 53 & 103 & 11 & 3.50 & Agree & 4 \\
\hline $\begin{array}{l}\text { Cost of involving external expertise to } \\
\text { assist the adoption of financial } \\
\text { reporting standards is high }\end{array}$ & 3 & 1 & 27 & 127 & 45 & 4.03 & Agree & 1 \\
$\begin{array}{l}\text { Cost of staff training and development } \\
\text { on financial reporting standards is } \\
\text { high compared to the benefit. }\end{array}$ & 5 & 111 & 72 & 11 & 3.40 & Agree & 5 \\
$\begin{array}{l}\text { The other operating costs associated } \\
\text { with adopting financial reporting } \\
\text { standards could be high. }\end{array}$ & 32 & 129 & 38 & 1 & 3.11 & Agree & 6 \\
\hline $\begin{array}{l}\text { It requires more staff to implement } \\
\text { which is expensive }\end{array}$ & 3 & 2 & 52 & 123 & 23 & 3.79 & Agree & 2 \\
\hline $\begin{array}{l}\text { Financial reporting standards differ } \\
\text { from other existing reporting } \\
\text { requirement which increases transition } \\
\text { cost }\end{array}$ & 11 & 79 & 82 & 26 & 3.56 & Agree & 3 \\
\hline
\end{tabular}

Table 5 above indicate that the highest mean value is 4.03 which shows that majority (172) of the respondents agreed (62.6\%) and strongly agreed
(22.2\%) that cost of involving external expertise to assist the adoption of financial reporting standards is high. Further, respondents asserted that it requires 
more staff to implement which is expensive; financial reporting standards differ from other existing reporting requirements which increases transition cost and the cost of changing or upgrading the accounting information system during the first adoption is high at the rate of $71.9 \% .53 .2 \%$ and $56.1 \%$ respectively. Further, Table 5 above shows that the majority of the respondents failed to decide on variables that state that cost of staff training and development on financial reporting standards is high compared to benefit and that other operating costs associated with adopting financial reporting standards could be high.

Hypothesis testing results indicate that cost of conversion has a significant effect on the decision to adopt financial reporting standards by MSMEs. The obtained P-value is 0.001 which is less than the critical value of 0.05 . This provides statistical evidence to conclude that based on the variable assessed, the cost of conversion has a significant effect on the decision to adopt financial reporting standards by MSMEs.

Table 6: Chi-square (x2) table for testing Hypothesis 2

\begin{tabular}{llll}
\hline & Value & df & Asymptotic Significance. (2-sided) \\
\hline Pearson Chi-Square & $52.620^{\mathrm{a}}$ & 24.001 \\
Likelihood Ratio & 50.916 & 24.001 \\
Linear-by-Linear Association & 13.784 & 1 & .000 \\
N of Valid Cases & 62 & \\
\hline
\end{tabular}

Legal and Regulatory Enforcement Strategy and Adoption of Financial Reporting Standards
Results of the data analysis on legal and regulatory enforcement strategy factors are shown in Table 7 below:

Table 7: Legal and regulatory enforcement strategy and adoption of financial reporting standards

\begin{tabular}{|c|c|c|c|c|c|c|c|c|}
\hline Assertions & SD & D & $\mathbf{N}$ & $\mathbf{A}$ & SA & Mean & Remarks & Ranking \\
\hline $\begin{array}{l}\text { Seminar, workshop, and other training } \\
\text { is not well monitored by the regulatory } \\
\text { body }\end{array}$ & 9 & 12 & 106 & 71 & 5 & 3.25 & Agree & 4 \\
\hline $\begin{array}{l}\text { Little effort is being made by a } \\
\text { regulatory body to encourage the } \\
\text { adoption of financial reporting } \\
\text { standards }\end{array}$ & 11 & 35 & 50 & 94 & 13 & 3.31 & Agree & 3 \\
\hline $\begin{array}{l}\text { There is no effective monitoring } \\
\text { mechanisms that ensure proper and } \\
\text { effective adoption and implementation } \\
\text { of the standards }\end{array}$ & 8 & 5 & 41 & 120 & 29 & 3.77 & Agree & 1 \\
\hline $\begin{array}{l}\text { Financial reporting standards are not } \\
\text { consistent with the local laws and } \\
\text { regulations }\end{array}$ & 9 & 9 & 99 & 72 & 14 & 3.36 & Agree & 2 \\
\hline
\end{tabular}

Table 7 above indicate that $149 \quad(73.4 \%)$ respondents agreed (120) and strongly agreed (29) that there is no proper and effective mechanism for monitoring the adoption and implementation of the standards with the mean value of 3.77. Similarly, respondents agreed and strongly agreed that seminars, workshops and other training are not well monitored by the regulatory body, little effort is being made by the regulatory body to encourage the adoption of standards and financial reporting 
standards are not consistent with the local laws and regulations with the mean value of $3.25,3.31$, and 3.36. Though in some cases majority of the respondents decided to remain neutral. Therefore, a low level of awareness creation and education provision result in inadequate knowledge, which hinders the smooth adoption and implementation of the financial reporting standards.
Table 8 indicates hypothesis testing results. The calculated Asymptotic Significance or P-value is 0.40. This P-value is less than the critical value of 0.05 . It is therefore fair to accept the hypothesis and conclude that legal and regulatory enforcement strategy has a significant effect on the decision to adopt financial reporting standards by MSMEs:

Table 8: Chi-square (x2) table for testing Hypothesis 3

\begin{tabular}{llll}
\hline & Value & df & Asymptotic Significance. (2-sided) \\
\hline Pearson Chi-Square & $44.631^{\text {a }}$ & 20 & .040 \\
Likelihood Ratio & 34.541 & 20 & .043 \\
Linear-by-Linear Association & 12.941 & 1 & .002 \\
N of Valid Cases & 62 & & \\
\hline
\end{tabular}

Level of Technology Applicability and Adoption of The statistical results are indicated in Table 9 below: Financial Reporting Standards

Table 9: Technology and adoption of financial reporting standards

\begin{tabular}{|c|c|c|c|c|c|c|c|c|}
\hline Assertions & SD & D & $\mathbf{N}$ & $\mathbf{A}$ & SA & Mean & Remarks & Ranking \\
\hline $\begin{array}{l}\text { There is a low level of technology } \\
\text { developments that affect the adoption } \\
\text { of financial reporting standards }\end{array}$ & 8 & 98 & 37 & 55 & 5 & 2.76 & Disagree & 4 \\
\hline $\begin{array}{l}\text { Continuous technological changes and } \\
\text { innovation negatively affect the } \\
\text { adoption and application of financial } \\
\text { reporting standards }\end{array}$ & 9 & 82 & 79 & 24 & 9 & 2.71 & Disagree & 5 \\
\hline $\begin{array}{l}\text { There is a low level of application of } \\
\text { computerised accounting systems } \\
\text { which affects the adoption of financial } \\
\text { reporting standards }\end{array}$ & 4 & 4 & 33 & 117 & 45 & 4.36 & Agree & 1 \\
\hline $\begin{array}{l}\text { There is a low level of investment in } \\
\text { technology infrastructure for adoption } \\
\text { of financial reporting standards }\end{array}$ & 7 & 18 & 31 & 129 & 18 & 3.86 & Agree & 3 \\
\hline $\begin{array}{l}\text { There is a shortage of well-trained } \\
\text { personnel on application of different } \\
\text { accounting package }\end{array}$ & 4 & 4 & 37 & 116 & 42 & 3.93 & Agree & 2 \\
\hline
\end{tabular}

Table 9 above indicates that the highest-ranked factor is "there is a low level of application of computerised accounting system which affects the adoption of financial reporting standards" this was asserted at $79.8 \%$ of the respondents, where 117 agreed and 45 strongly agreed. The result also shows that within the SMEs, there is a low level of investment in technology infrastructure and there is 
a shortage of well-trained personnel for the application of different accounting package with the mean value of 3.93 and 3.86 , respectively. However, the majority disagreed and strongly disagreed that there is a low level of technological developments that limit the adoption of standards and that continuous technological changes and innovation obstacle the adoption and applicability of financial reporting standards.
The hypothesis testing result indicates that technology has no significant effect on the decision to adopt financial reporting standards. This is because the obtained P-value is 0.061 which is greater than the critical value of 0.05 . therefore, this provides statistical evidence to reject the hypothesis

Table 10: Chi-square (x2) table for testing Hypothesis 4

\begin{tabular}{llll}
\hline & Value & df & Asymptotic Significance. (2-sided) \\
\hline Pearson Chi-Square & $33.074^{\mathrm{a}}$ & 22 & .061 \\
Likelihood Ratio & 32.741 & 22 & .066 \\
Linear-by-Linear Association & 9.719 & 1 & .002 \\
N of Valid Cases & 62 & & \\
\hline
\end{tabular}

Complexity of the Standards and Adoption of Summary of the results of the descriptive statistics Financial Reporting Standards are indicated in Table 11 below:

Table 11: Complexity of the standards and the adoption of the financial reporting standards

\begin{tabular}{lllllllll}
\hline Assertions & SD & D & N & A & SA & Mean & Remarks & Rankings \\
\hline $\begin{array}{l}\text { Accounting standards and their } \\
\text { requirement are difficult to } \\
\text { understand, interpret and }\end{array}$ & 7 & 19 & 78 & 94 & 5 & 3.35 & Agree & 4 \\
implement & & & & & & & & \\
\hline $\begin{array}{l}\text { There is inadequate representation } \\
\text { of micro, small, and medium-sized } \\
\text { entity on standards-setting } \\
\text { processes }\end{array}$ & 22 & 65 & 92 & 16 & 3.42 & Agree & 3 \\
$\begin{array}{l}\text { There is inadequate technical } \\
\text { guidelines and other supporting } \\
\text { materials for the successful } \\
\text { adoption of the standards }\end{array}$ & 19 & 51 & 119 & 6 & 3.47 & Agree & 2 \\
\hline $\begin{array}{l}\text { There is a low level of technical } \\
\text { knowledge Among the SMEs }\end{array}$ & 6 & 59 & 105 & 26 & 3.67 & Agree & 1 \\
\hline $\begin{array}{l}\text { Financial reporting standard } \\
\text { increase reporting and disclosure } \\
\text { requirements which increase } \\
\text { complexity to SMEs }\end{array}$ & 26 & 79 & 85 & 5 & 3.26 & Agree & 5 \\
\hline
\end{tabular}

Specifically, as shown in Table 11 above, 131 $(64.5 \%)$ respondents agreed and strongly agreed that a low level of technical knowledge among SMEs obstacle the adoption of the standards with the mean value of 3.067 , which is the highest mean value score. Generally, in all assertions, as indicated in Table 8 above majority of the respondents were from those who either agreed or strongly agreed. Also, in some cases, a significant number of respondents were not able to decide; this is an 
indication of the existence of inadequate knowledge on the standards by the respondents. Similarly, Mawutor et al. (2019) from Ghana concluded that the complexity of IFRS for SMEs caused difficulties in the adoption of the standards.

Hypothesis testing results as indicated in Table 12 were consistent with the result obtained from the Table 12: Chi-square (x2) table for testing Hypothesis 5

\begin{tabular}{llll}
\hline & Value & df & Asymptotic Significance. (2-sided) \\
\hline Pearson Chi-Square & $56.890^{\mathrm{a}}$ & 26 & .000 \\
Likelihood Ratio & 53.025 & 26 & .001 \\
Linear-by-Linear Association & 14.802 & 1 & .000 \\
N of Valid Cases & 62 & & \\
\hline
\end{tabular}

\section{DISCUSSION OF RESULTS}

The main purpose of this study was to assess factors affecting the adoption of financial reporting standards by Micro, Small, and Medium Enterprises in Tanzania. This was after noticing from different literature that the majority of the SMEs do not use basic accounting practices in managing business though Tanzania adopted financial reporting standards for SMEs in 2009. The following subsection discusses the main findings for each specific study objectives

\section{Level of Education and Training on Financial Reporting Standards}

The study result shows that the majority of the MSMEs do not have adequate education and lack knowledge of financial reporting standards. This impliedly indicates that little effort has been made by the responsible body to facilitate the adoption of the financial reporting standards by ensuring that a large number of MSMEs players are adequately educated and have sufficient information on the availability and requirement of the financial reporting standards. On another hand, the result shows that there is a reasonable number of educational institutions that train accountancy professionals, but the graduate from those institutions have inadequate knowledge of the descriptive statistics. The obtained P-value of 0.000 is less than the critical value of 0.05 which provide statistical evidence to accept the hypothesis and conclude that standards complexity has a significant influence on the decision to adopt the financial reporting standards adopted standards; this means that the training institution curriculum does not adequately cover issues relating to the standard. The prevailing situation limits adequate adoption of financial reporting standards by MSMEs because knowledge is the backbone for the successful adoption of financial reporting standards. Hypothesis testing results also provide statistical evidence to conclude that level of education and training has a significant effect on the adoption of financial reporting. Therefore, a low level of education and training hinder the adoption of the standards by MSMEs. The study result is consistent with the finding from the study conducted by Ssenyonga (2019) in Uganda where it was noted that lack of required skill, lack of practical knowledge, and lack of knowledge on the existence of the standard hinder the adoption of the standards in Uganda. Similar results were noted from the study conducted on the adoption of IFRS for SMEs by Arhin et al. (2017); Mawutor et al. (2019) in Ghana. This indicates that most of the developing countries face the challenges of inadequate knowledge on the process to adopt the issued standards by SMEs.

\section{Cost of Conversion and Adoption of Financial Reporting Standards}

Findings on the cost of conversion showed that firms hesitate to adopt financial reporting standards 
due to the perception that the cost of adoption could be high. This is because within the MSMEs, there is a missing required skill for adequate adoption of the standards. Therefore, they should engage an expert to assist the adoption and formulation or upgrading of accounting information systems that will ensure proper control, accuracy, and completeness in record keeping. In some cases, respondents were not able to provide an opinion; this is attributed to a lack of knowledge on the requirement of the standards. Hypothesis testing results also show that cost of conversion has a significant effect on the decision to adopt financial reporting standards, an obstacle to the adoption of the standards. The study finding is consistent with the finding from the study conducted by Kılıç and Uyar (2017); Ssenyonga (2019); Hussain et al. (2012); Mawutor et al. (2019); Rudzani and Charles (2016) and Litjens et al. (2012) where it was revealed that cots of conversion hinder the adoption of the financial reporting standards by SMEs

\section{Legal and Regulatory Enforcement Strategy and Adoption of Financial Reporting Standards}

With regards to Legal and regulatory enforcement strategy, the result shows that there is a weak legal and regulatory enforcement strategy. In Tanzania, the adoption of financial reporting standards by SMEs is permitted and not required. Therefore, there is no mandatory requirement for SMEs to prepare financial statements in accordance with financial reporting standards. Due to this, SMEs prepare financial reports to meet their preferences depending on users' requirements. The main user of the SME financial information are tax authority and lenders; therefore, SMEs prepare a financial report to meet the need of those users, this cause inconsistency and absence of comparability between SMEs' financial information. Hypothesis testing results show that legal and regulatory enforcement strategy has a significant effect on the decision to adopt financial reporting standards.
Therefore, the regulatory body has an important role to play to facilitate the adoption of the standards. Similar results were reported by Arhin et al. (2017) in Ghana, where it was revealed that regulatory and professional bodies were not supporting SMEs to implement IFRS for SMEs while SMEs expected that regulatory body could have organised seminars and training, also could have formulated a team of professional to work in line with SMEs to identify the challenges they face and solve them accordingly.

\section{Technology and Adoption of Financial Reporting Standards}

The study results show that MSMEs perceive technology to be one of the paramount sources of cost on the adoption of financial reporting standards. The adoption of financial reporting standards requires proper record keeping and most businesses have a large volume of small transactions which must be properly recorded. Therefore, technology provides a better solution because the large volume of data can be processed and stored through technology and produce reliable, accurate, and quality financial reports on time. However, within MSMEs business, there is a low level of investment in technology which causes most SMEs to halt the adoption of the financial reporting standards because they should first invest in information technology infrastructure and engage someone with a technological expert or train the existing staff which increases the cost.

The study conducted by Amanamah et al. (2016) in Ghana revealed that only a few SMEs are able to use computerised accounting systems due to perception of high cost and lack of technical personnel which results in poor information management and poor data storage for financial reporting purposes. Therefore, to adopt financial reporting standards, there is a need for SMEs to take up the challenge to ensure that data are properly maintained. Though hypothesis testing results indicate that technology 
has no significant effect on the decision to adopt financial reporting standards

\section{Complexity of the Standards}

With regard to the complexity of the standards, the result shows that respondents agreed that financial reporting standards are too complex for MSMEs that it needs someone who is well trained on financial reporting standards, but this expertise is missing within the MSMEs. Therefore, there is a need for an assessment of the suitability of the adopted standards in Tanzania to see if the adopted standards are appropriate as it may increase the compliance burden to small entities. Further adequate training is needed for SMEs to be able to adapt. Similarly, hypothesis testing results show that standards complexity has a significant effect on the decision to adopt financial reporting standards. Samugh and Devi (2015) argued that the low level of adoption of financial reporting standards by SMEs is contributed by the complexity of the standards and low level of technical knowledge. Rudzani and Charles (2016) concurred with the aforementioned challenges and suggested the review of IFRS for SMEs to reduce complexity.

\section{CONCLUSION AND RECOMMENDATION}

The study results show that currently IFRS for SMEs and FRSMEs is not well known by the majority of the MSMEs in Tanzania which means that the objective for the establishment of the standards cannot be achieved. The study recommends the government through NBAA to increase the effort on bringing awareness on financial reporting standards. This should include the use of a curriculum that addresses the challenges of financial reporting standards and use competency-based education training (CBET) to enable graduands to link what they learn in class with practise at work. Further IFRS for SMEs and FRSME should be considered as subjects to enable detailed training to students.
To enforce the adoption of the standards, the government is advised to use regulatory authorities like Tanzania revenue authority (TRA), NBAA, Bank of Tanzania (BOT), and other relevant authorities to encourage the adoption because it was noticed that majority of the MSMEs prepare a financial report to comply with certain regulatory requirements. Further, the study recommends a regulatory body, particularly the National Board of Accountants and Auditors (NBAA) to conduct an assessment on the suitability of the adopted standards in Tanzania. The assessment should aim at coming up with a solution on different issues challenging MSMEs because it was noted that most of the micro and small entities do not prepare a financial statement as they perceive that the adoption of financial reporting standards increases the compliance burden to them.

The study also recommends SMEs to employ and use the right person in each position based on their academic qualification and they should develop awareness to the employee on financial reporting standards through training and workshop.

\section{REFERENCES}

Adekoya, O. (2011). Similarities and differences, IFRS and Nigerian GAAP. Lagos: Pricewater House Coopers International Limited. (pwCIL).

Alia, M., \& Branson, J. (2011). The effect of environmental factors on accounting diversity. A literature review. 2011, P 04, Available at SSRN: https://ssrn. com/abstract, 1780479.

Albu, C. N. (2013). How relevant is size for setting the scope of the IFRS for SMEs. Accounting and Management Information Systems.

Amanamah, R. B., Morrison, A., \& Asiedu, K. (2016). Computerised accounting systems usage by small and medium scale enterprises in Kumasi Metropolis, Ghana. Research Journal of Finance and Accounting, 7(16), 16-29. 
Arhin, T., Perprem, A., \& Hulede, A. (2017). The challenges of adoption and implementing IFRS for SMEs in Ghana. a case of SMEs in the Kumasi metropolis. Research Journal of Accounting.

Berisha, G., \& Pula, J. S. (2015). Defining Small and Medium Enterprises: a critical review. Academic Journal of Business, Administration, Law and Social Sciences, 1(1), 17-28.

Cochran, W. G. (1977). Sampling Techniques. New York: John Wiley and Sons, Inc.

DiMaggio, P. J., \& Powell, W. W. (1983). The iron cage revisited: Institutional isomorphism and collective rationality in organisational fields. American Sociological Review, 147-160.

Emekaponuzo, D. E., Jeremiah, O. O., \& Alfred, E. J. (2017). Information technology implications of IFRS implementation in Nigeria: Challenges to auditors. Journal of Investment and Management, 6(1), 22-27.

Guyashi, K., \& Miku, F. (2015). Effectiveness in Tax Payment by Rural Micro Enterprises in Tanzania. Journal of Economics and Sustainable Development, 6 (21), 88-93.

Hussain, F. F., Chand, P. V., \& Rani, P. (2012). The impact of IFRS for SMEs on the accounting profession: Evidence from Fiji. Accounting \& Taxation, 4(2), 107-118.

IASB. (2020). Issued standards-The IFRS for SMEs Standard. Retrieved from IFRS: https://www.ifr s.org/issued-standards/ifrs-for-smes/

IFRSFoundation. (2015). International Financial Reporting Standard for Small and Medium-sized Entities (IFRS for SMES). London: IFRS Foundation Publications Department.

International Accounting Standards Board. (2015). The International Financial Reporting Standard for Small and Medium-sized Entities (IFRS for $S M E s)$. London: IFRS Foundation.

Jayabalan, J., Raman, M., Dorasamy, M., \& Ching, N. K. C. (2009). Outsourcing of accounting functions amongst SME companies in Malaysia: An exploratory study. Accountancy Business and the Public Interest, 8(2), 96-114.

Kaur, J. (2013). Techniques Used in Hypothesis Testing in Research Methodology - A Review. International Journal of Science and Research (IJSR), 363-364.

Kaya, D., \& Koch, M. (2015). Countries' adoption of the International Financial Reporting Standard for Small and Medium-sized Entities (IFRS for SMEs)-early empirical evidence. Accounting and Business Research, 45(1), 93120.

Kenneth, M., \& Grazyina, M. (2013). The adoption of international financial reporting standards for small to medium enterprises in Zimbabwe. International Journal of Asian Social Science, 3(11), 2315-2349.

Khoury, S. (2009). Public, private or non-profit: How IFRS can add value to your Information Systems.

Kibona, I. (2020). Financial management practices and performance of Micro, small and medium enterprises (MSMEs) in Tanzania: A case of Kibaha Town Council. Morogoro: Mzumbe university.

Kiliç, M., \& Uyar, A. (2017). Adoption process of IFRS for SMEs in Turkey: Insights from academics and accountants. Accounting and Management Information Systems, 16(2), 313339.

Litjens, R., Bissessur, S., Langendijk, H., \& Vergoossen, R. (2012). How do preparers perceive costs and benefits of IFRS for SMEs? 
Empirical evidence from the Netherlands. Accounting in Europe, 9(2), 227-250.

Lukumay, B. L. (2018). Impact of accounting practices on financial performance of SMEs in Ilala district of Tanzania. International Academic Journal of Human Resource and Business Administration, 1 (4), 50-51

Mawutor, J. K. M., Williams, S., \& Oduwaa, M. A. (2019). Assessment of the adoption and implementation of IFRS for small and medium scale entities (SMEs). "A study of selected SMEs GA East of Ghana. Asian Journal of Finance \& Accounting, 11(1), 24-258.

Mkasiwa, T. A. (2014). SMEs' Financial and Differential Reporting-A Review of Publications. International Journal of Accounting and Financial Reporting, 4(2), 82.

Moll, J., Burns, J., \& Major, M. (2006). Institutional Theory In Hoque, Z.(ed). Methodological issues in accounting research: theories, methods and issues.

Msuya, R., \& Maleko, G. (2015). Non-compliance and Challenges of Implementing IFRS in Saving and Credits Cooperative Societies (SACCOS) in Shinyanga Region" "Tanzania. Journal of Business Administration and Education, 7(1).

Mwakujonga, J., \& Bwana, K. M. (2013). The practice of preparing and using financial information in financial decisions: a survey of SMEs in Tanzania. European Journal of Business and Management, 5 (9), 161-169.

National Board of Accountants and Auditors (NBAA). (2018). Technical Updates. Retrieved from The United Republic of Tanzania: National Board of Accountant and Auditors (NBAA): https://www.nbaa.go.tz/pages/technical-updates

Nzunda, F. W. (2013). The compliance and noncompliance of Tanzania small and medium enterprises (SME's) to international financial reporting standards IFRS's) the survey made at Morogoro municipal. Mzumbe University.

Perera, D., \& Chand, P. (2015). Issues in the adoption of international financial reporting standards (IFRS) for small and medium-sized enterprises (SMES). Advances in accounting, 31(1), 165-178.

Rudzani, S., \& Charles, M. D. (2016). An assessment of the challenges of adopting and implementing IFRSS for SMEs in South Africa. Problems and perspectives in management, (14, Iss. 2 (contin. 1)), 212-221.

Samujh, H., \& Devi, S. S. (2015). Implementing IFRS for SMEs: Challenges for developing economies. International Journal of Management and Sustainability, 4(3), 39-59.

Saunders, M., Lewis, P., \& Thornhill, A. (2009). Research Methods for Business Students. London: Pearson Education Limited.

Ssenyonga, Y. (2019). Adoption of International Financial Reporting Standard for Small and Medium Entities as a Financial Reporting Framework; A case study of the Greater Kampala Metropolitan Area. Makerere University.

Tavakol, M., \& Dennick, R. (2011). Making sense of Cronbach's alpha. International journal of medical education, 2, 53.

Zeghal, D., \& Mhedhbi, K. (2006). An analysis of the factors affecting the adoption of international accounting standards by developing countries. The International Journal of Accounting, 373386. 